\title{
Effects of Plant Pattern and Nitrogen Fertilizer on Yield and Yield Components of Silage Corn Cultivars
}

\author{
Mohammad Hossein Haddadi \\ Scientific member of Agronomic and Horticulture Crops Research Department, Mazandaran \\ Agricultural and Natural Resources Research and Education Center, AREEO, Sari, \\ Iran.Box:48175-556 \\ Masoud Mohseni \\ Scientific member of Agronomic and Horticulture Crops Research Department, Mazandaran \\ Agricultural and Natural Resources Research and Education Center, AREEO, Sari, Iran
}

Received: January 18, 2016 Accepted: January 23, 2016 Published: February 14, 2016

doi:10.5296/jas.v4i1.8883 URL: http://dx.doi.org/10.5296/jas.v4i1.8883

\begin{abstract}
To study effect of sowing pattern and nitrogen on maize silage yield and its dependents components a trial was done at split-split plot design in completely randomized block at four replications in Qrakheil (Qaemshahr) agricultural research station in 2015 in Iran. Row spacing was chosen as main plots including: $65 \mathrm{~cm}, 75 \mathrm{~cm}$ and $85 \mathrm{~cm}$. Two cultivars (Sc704 and Sc770) in sub plots and three levels of $\mathrm{N}(250,350$ and $450 \mathrm{~kg}$ ha1) in sub-sub plots were laid out. Silage forage yield, ear and dry ear yield, leaf and dry leaf yield, plant dry weight and stem and dry stem weight, plant height, ear height, kernel number in ear row and row number in ear were measured. The results indicated that row spacing, were not affected on investigated traits. While nitrogen effected on silage yield, ear and dry ear yield, leaf and dry leaf yield, plant dry weight and stem and dry stem weight, plant height and ear height and showed significant difference. Sc704 had significant difference on plant silage weight, dry and wet stem weight with Sc770. Amount of $350 \mathrm{~kg} / \mathrm{ha}$ nitrogen was caused the most silage yield (36.74t/ha) and plant dry weight (16.64 t/ha) that had not significant difference with usage of $450 \mathrm{~kg} / \mathrm{ha}$ nitrogen $(16.46 \mathrm{t} / \mathrm{ha})$. Amount of $450 \mathrm{~kg} / \mathrm{ha}$ nitrogen was caused the most silage yield (37.30t/ha) that had not significant difference with usage of $350 \mathrm{~kg} / \mathrm{ha}$ nitrogen (36.74 t/ha). The most silage yield (38.21t/ha) obtained from Sc704 that was better than Sc770 (34.22 t/ha). The most plant dry weight (16.54) obtained from Sc704 that had not significant difference with Sc770 (15.92 t/ha).
\end{abstract}

Keywords: Corn, nitrogen and potassium fertilizer, row spacing. 


\section{Introduction}

Maize (Zea maize L. ) is importance grain-forage plant in Iran (Hashemi, et al 2005).

The mean kernel yield of maize is greater than eight $t /$ ha and produce increase each years. New hybrids for each location can increase maize yield (Allard, 1960 ). maize have importance role in the live of the people of Americas (Kiniry et al., 1992).

Maize requires three main element nitrogen $(\mathrm{N}$ ) potassium $(\mathrm{K})$ and phosphorus $(\mathrm{P}$ and on most soils, the amount of nitrogen is very much needed and provide sufficient nitrogen in various stages of growth for having a good performance(Tad,2004). according to the study conducted by subedi et al (2006), nitrogen consumption increased corn silage yield. Amount of corn nitrogen necessary depends on the silage yield when no restrictions have on the other elements( Pampolino et al 2007 ).nitrogen application have significant effect on qualitative and quantitative maize yield( sanjeev and Bangawa ,1997). Application of nitrogen is appropriate method for increasing the yield of corn (Norwood, 2000).Study have shown that the best response of maize to nitrogen was 250 and $300 \mathrm{~kg}$ per hectare net nitrogen (Di paolo and Rinaldi, 2008). Nitrogen is a importance factor for corn growth (Adediran and Banjoko, 1995,.Tollenaar and Aguilera. 1992).Protein and nucleic acids have nitrogen and when Nitrogen is no sufficient; produce is reduced (Haque et al., 2001).For suitable corn growth it is necessary that nitrogen must be enough,throut the growing period. Nitrogen is a necessary element for many other essential compounds for plant growth processes such as chlorophyll and many enzymes. It is also necessary for using of phosphorus, potassium and other elements in plants (Brady, 1984). Therefore, deficiency or excess of nitrogen were caused reduces of corn produce. Sowing pattern is a main factor that determines the produce of corn (Cardwell, 1982). Sowing method affects germination, water requirements of crop, growth and development of roots and exploitation of moisture from soil layers. If plants have a suitable pattern, water and nutrients is better utilized (Ali et al ,1998). Efficiency of radiation use is influenced by Sowing pattern. Sowing of corn in narrow rows results increasing light using for each plant. Therefore, narrow rows increase photosynthetic activity and yield (Tollenaar and Aguilera, 1992).Suitable plant density was caused increasing. Maize have low tolerance to high plant density. Maize yield was negatively correlated to radiation interception at time of pollination with the wider spacing (Andrade et al., 2002 ). Higher yields were obtained for maize in narrow rows vs. wide rows regardless of hybrids and plant density in Indiana and Michigan (Widdcombe and Thelen, 2002).

Narrower row spacing with higher plant density results in a more equidistant planting pattern, is expected to delay initiation of intra specific competition (Duncan , 1984). Early crop growth is increased with narrow row spacing(Bullock et al 1988). Optimum row spacing differs among plant genotype; yields will generally be maximized by sowing in rows an equidistant spacing among plants (Saseendranet al, 2005). Narrow-row has been advocated in recent years to increase grain yield (Kucharik. 2008). These differences in yield associated with row spacing appear to be emphasize for corn grown at more northerly location within the U.S. Corn Belt (Saseendran et al, 2005).Positive response was showed in yield of corn in narrower rows (Ottman and Welch,1989). An 11\% lower yield for corn grown in 0.19- m rows vs. 0.38- and 0.76-m rows in Wisconsin was shoewd (Pedersen and Lauer, 2003). Farnham (2001) showed a 
$2 \%$ decreasing yield for maize grown in 0.38 -m rows vs. $0.76-\mathrm{m}$ rows in Iowa.

\section{Material and Methods}

The study was done at the Agricultural Research station of Mazandran in Qaemshahr $\left(31^{\circ} 28^{\prime} \mathrm{N}\right.$, $52^{\circ} 35^{\prime} \mathrm{E}$, and an altitude of 14.7 meters above of sea level) in Iran. The soil type was clay loam.

To determine the effect of plant pattern, nitrogen on forage yield and its dependents components on corn (Zea mays L. SC704 and SC770), an experiment was done as split-split plot with a randomized complete block design in Qrakheil (Qaemshahr) agricultural research station in 2015in Iran. Main plot is row space $(\mathrm{P} 1=65 \mathrm{~cm}, \mathrm{P} 2=75 \mathrm{~cm}, \mathrm{P} 3=85 \mathrm{~cm})$, sub plot is cultivar V1=SC704andV2=SC770, sub-sub plot is nitrogen $(\mathrm{N} 1=250 \mathrm{~kg} / \mathrm{ha}, \mathrm{N} 2=350 \mathrm{~kg} / \mathrm{ha}$, $\mathrm{N} 3=450 \mathrm{~kg} / \mathrm{ha}$ Urea manure).Plant at each treatment were planted at four rows an four replications.

Weeds control was done with hand. Irrigation was done with a sprinkler system. Plants in each treatment harvested separately. Plants were cut done at the two middle rows in the plots (Area of $9 \mathrm{~m}^{2}$ ). In harvest time, plants in each plot were weighted then dry and wet ear, stem, leaves and silage yield were measured. Number of kernel in ear row, number of row in ear, ear height $(\mathrm{cm})$ and plant height $(\mathrm{cm})$ also were measured. Data was analyzed by MSTAT-C procedure .The DMRT procedure was used to make tests of simple and interaction effects. All differences are significant at $\mathrm{P}<0.05$ unless otherwise stated.

\section{Result and Discussion}

\subsection{Plant height}

The highest plant height was in related to SC770 with $251.7 \mathrm{~cm}$. There was $235.9 \mathrm{~cm}$ and $162.8 \mathrm{~cm}$ plant height for SC704.

Row spacing had not significant effect on plant height. Lowest plant height was in related to row spacing of $65 \mathrm{~cm}(241.3 \mathrm{~cm})$. Row spacing of $85 \mathrm{~cm}(245.7$ plant $/$ ha) and $75 \mathrm{~cm}(244.4$ plant/ha) have highest plant height (Table 2).Nitrogen had significant effect on dry silage yield. The highest plant height was obtained from $450 \mathrm{~kg} / \mathrm{ha} \mathrm{N}(246.8 \mathrm{~cm})$. The lowest plant height was obtained from $250 \mathrm{~kg} / \mathrm{ha} \mathrm{N}(240.0 \mathrm{~cm})$ (Table 2).

\subsection{Ear height}

SC704 had highest ear hight $(116.4 \mathrm{~cm}) . S C 770(115.56 \mathrm{~cm})$ had less ear hight than SC704but no significant difference had between cultivars. There is not significant difference between row spacing . Row spacing of $85 \mathrm{~cm}$ and $65 \mathrm{~cm}$ had higher ear height with $117.9 \mathrm{~cm}$ and 116.5 $\mathrm{cm}$ respectively. Nitrogen had significant effect on ear hight. The highest ear hight was obtained from $450 \mathrm{~kg} / \mathrm{ha} \mathrm{N}(118.7 \mathrm{~cm})$. The lowest ear height was obtained from $250 \mathrm{~kg} / \mathrm{ha} \mathrm{N}$ $(113.4 \mathrm{~cm})$ (Table 2).

\subsection{Kernel Row Number}

Cultivars were nearly similar in point of kernel row number and had not significant difference. SC770 and SC704 had 15.44and 15.61 kernel row number respectively.Row spacing had not significant difference at this trait. Row spacing of $65 \mathrm{~cm}$ had the highest kernel row number(15.58n) (Table 2).Nitrogen had not significant difference on this trait. $450 \mathrm{~kg} / \mathrm{haN}$ had the highest kernel row number(36.54n) (Table 2).

\subsection{Kernel number in ear row}


There was no difference effect between cultivars on kernel number in ear row .SC704 had the highest kernel number in ear row with 36.14n.SC770 had 35.94n) .The highest kernel row in ear row with $30.33 \mathrm{n}$ was optained from $75000 \mathrm{p} / \mathrm{ha}$.Row spacing had not significant different effect on this trait.Row spacing of $65 \mathrm{~cm}, 75 \mathrm{~cm}$ and $85 \mathrm{~cm}$, had $36.50,35.79$ and $35.83 \mathrm{n}$ kernel row in ear row respectively (Table 2).

Table 1. Variance analysis of experimental traits

\begin{tabular}{cccccc}
\hline Source of variation & df & $\begin{array}{c}\text { Kernel number in } \\
\text { row }\end{array}$ & $\begin{array}{c}\text { Row } \\
\text { number }\end{array}$ & Plant height $(\mathrm{cm})$ & $\begin{array}{c}\text { Plant } \\
\text { height }(\mathrm{cm})\end{array}$ \\
\hline Replication & 3 & $67.09 \mathrm{~ns}$ & $0.65 \mathrm{~ns}$ & $41.57 \mathrm{~ns}$ & $1155.61^{*}$ \\
Row spacing & 2 & $3.79 \mathrm{~ns}$ & $0.06 \mathrm{~ns}$ & $115.26 \mathrm{~ns}$ & $120.68 \mathrm{~ns}$ \\
Error(a) & 6 & 22.31 & 5.32 & 61.26 & 159.18 \\
Cultivar(b) & 1 & $0.67 \mathrm{~ns}$ & $0.500 \mathrm{~ns}$ & $15.13 \mathrm{~ns}$ & $4449.39 *$ \\
Row spacingx & 2 & $1.68 \mathrm{~ns}$ & $1.17 \mathrm{~ns}$ & $51.54 \mathrm{~ns}$ & $270.01 \mathrm{~ns}$ \\
Cultivar & 9 & 44.16 & 1.09 & 175.99 & 250.73 \\
Error(b) & 2 & $4.54 \mathrm{~ns}$ & $1.72 \mathrm{~ns}$ & $168.43 \mathrm{~ns}$ & $284.26 \mathrm{~ns}$ \\
N(c) & 4 & $53.08 *$ & $2.72 \mathrm{~ns}$ & $73.18 \mathrm{~ns}$ & $69.41 \mathrm{~ns}$ \\
Row spacingxN & 2 & $30.85 \mathrm{~ns}$ & $1.50 \mathrm{~ns}$ & $41.63 \mathrm{~ns}$ & $78.43 \mathrm{~ns}$ \\
CultivarxN & & & & $76.79 \mathrm{~ns}$ & $233.37 \mathrm{~ns}$ \\
Row & 4 & $86.97 * *$ & $0.17 \mathrm{~ns}$ & 75.39 & 206.93 \\
spacingxCultivarxN & & 18.66 & 1.43 & 7.49 & 5.90 \\
Error(c) & 36 & 11.98 & 7.69 & \\
\hline \%CV & 3 & $1 \%$ and & & \\
\hline
\end{tabular}

$*, * *$ and ns significant at the 5\%,1\% and non-significant respectively.

Table 2. Mean comparison of different treatments for the studied agronomic characteristics in corn Treatments Kernel number in row Row number Ear height $(\mathrm{cm}) \quad$ Plant height $(\mathrm{cm})$

Row spacing

\begin{tabular}{ccccc}
\hline $65 \mathrm{~cm}$ & $36.50 \mathrm{a}$ & $15.58 \mathrm{a}$ & $116.5 \mathrm{a}$ & $241.3 \mathrm{a}$ \\
$75 \mathrm{~cm}$ & $35.79 \mathrm{a}$ & $15.50 \mathrm{a}$ & $113.6 \mathrm{a}$ & $244.4 \mathrm{a}$ \\
$85 \mathrm{~cm}$ & $35.83 \mathrm{a}$ & $15.50 \mathrm{a}$ & $117.9 \mathrm{a}$ & $245.7 \mathrm{a}$ \\
Cultivar & & & & \\
Sc704 & $36.14 \mathrm{a}$ & $15.44 \mathrm{a}$ & $116.4 \mathrm{a}$ & $235.9 \mathrm{~b}$ \\
$\mathrm{Sc770}$ & $35.94 \mathrm{a}$ & $15.61 \mathrm{a}$ & $115.5 \mathrm{a}$ & $251.7 \mathrm{a}$ \\
$\mathrm{N}$ & & & \\
$\mathrm{Kg} 250$ & $15.42 \mathrm{a}$ & $35.75 \mathrm{a}$ & $113.4 \mathrm{c}$ & $240.0 \mathrm{c}$ \\
$\mathrm{Kg} 350$ & $15.83 \mathrm{a}$ & $35.83 \mathrm{a}$ & $115.8 \mathrm{~b}$ & $244.6 \mathrm{~b}$ \\
$\mathrm{Kg} 450$ & $15.33 \mathrm{a}$ & $36.54 \mathrm{a}$ & $118.7 \mathrm{a}$ & $246.8 \mathrm{a}$ \\
\hline
\end{tabular}

Means followed by the same letters in each column and factor are not significantly different by Duncan's test at 5\% probability level. 


\subsection{Silage yield}

Variance analysis and means comparision of traites was shown in tables 3 and 4. Row spacing had not a significant effect on silage yield (Table 4 ). The highest silage yield was produced in $65 \mathrm{~cm}$ row spacing with 66.54and $36.30 \mathrm{t} / \mathrm{ha}$.The lowest silage yield(34.21) was produced in $250 \mathrm{~kg} / \mathrm{ha}$ nitrogen(Urea manure) with $34.21 \mathrm{t} / \mathrm{ha}$. Amount of $250 \mathrm{~kg} / \mathrm{ha}$ and $350 \mathrm{~kg} / \mathrm{ha}$ nitrogen produced highest silage yield with 36.74 and 37.30 t/ha respectively. There is no significant difference between $350 \mathrm{~kg} / \mathrm{ha}$ and $450 \mathrm{~kg} / \mathrm{ha}$ nitrogen on silage yield.SC704 produced the highest silage yield with $38.21 \mathrm{t} / \mathrm{ha}$. The lowest silage yield(34.22 t/ha) were produced in related to SC770(Table4). Light interception was not affected by corn row spacing. No yield advantage was showed in narrow (spacing of $0.38 \mathrm{~m}$ ) rows vs. conventional (spacing of $0.76 \mathrm{~m}$ ) rows in maize at two growing seasons in Minnesota (Westgate et al.,1997).

Nitrogen is the main element in increasing productivity and the increase of agricultural food production worldwide over the past four decades (Rahimizadeh, 2010), but large amount of fertilizer $\mathrm{N}$ was caused a serious environmental problem such as groundwater ontamination. In investigation of comparing liquid swine manure with chemical $\mathrm{N}$ and $\mathrm{P}$ fertilizer sources, maize yield and $\mathrm{N}$ and $\mathrm{P}$ uptake was similar for both $\mathrm{N}$ sources (Asghar et al ,2010).

\subsection{Dry and wet leaf weight}

Cultivars were nearly same in point of dry and wet leaf weight,SC770 had the higher and lower dry and wet leaf weight with 2.13t/ha and $6.56 \mathrm{t} /$ ha than SC704 with $2.11 \mathrm{t} / \mathrm{ha}$ and 6.60 t/ha(Table 4and Table 6). The lowest wet leaf weight was in related to $250 \mathrm{~kg} / \mathrm{ha}$ with $5.87 \mathrm{t} / \mathrm{ha} .350 \mathrm{~kg} / \mathrm{haN}(6.99 \mathrm{t} / \mathrm{ha})$ and $450 \mathrm{~kg} / \mathrm{ha} \mathrm{N}(6.89 \mathrm{t} / \mathrm{ha})$ effects had not significant difference on this trait. There was no difference effect between row spacings on dry and wet leaf weight(Table 4and Table 6).The highest and lowest wet leaf weight was obtained from $75 \mathrm{~cm}(7.09 \mathrm{t} / \mathrm{ha})$ and $65 \mathrm{~cm}(6.02 \mathrm{t} / \mathrm{ha})$ respectively. Nitrogen had not significant effect on dry leaf weight. The lowest dry leaf weight was in related to $250 \mathrm{~kg} /$ ha with $2.10 \mathrm{t} / \mathrm{ha}$ (Table 6).

\subsection{Dry and wet stem weight}

SC704 had the highest dry and wet stem weight with 7.77 t/ha and $18.47 \mathrm{t} /$ ha in compare of SC770 with 6.53 t/ha and 14.82t/ha respectively. Row spacings had not significant difference on dry and wet stem weight (Table 4and Table 6).Nitrogen had significant effect on dry and wet stem weight. The lowest wet stem weight was obtained from $250 \mathrm{~kg} / \mathrm{ha} \mathrm{N}$ with $15.8 \mathrm{t} / \mathrm{ha}$. $350 \mathrm{~kg} / \mathrm{ha} \mathrm{N}$ with16.65t/ha and 450kg/ha Nwith17.07t/ha wet stem weight had not significant difference on wet stem weight. The lowest dry stem weight was obtained from $250 \mathrm{~kg} / \mathrm{ha} \mathrm{N}$ with $6.82 \mathrm{t} / \mathrm{ha} .350 \mathrm{~kg} / \mathrm{ha} \mathrm{N}$ with7.48 t/ha and $450 \mathrm{~kg} / \mathrm{ha} \mathrm{Nwith7.17t/ha} \mathrm{dry} \mathrm{stem} \mathrm{weight} \mathrm{had} \mathrm{not}$ significant difference on dry stem weight (Table 6).

\subsection{Dry and wet ear weight}

Row spacings had not significant difference on dry and wet ear weight $.65 \mathrm{~cm}$ row spacing had highest dry and wet stem weight with 13.10 t/ha and 7.52 t/ha respectively.SC704 had higher wet ear weight (13.14t/ha) than SC770(12.84t/ha). SC770 had higher dry ear weight $(7.26 \mathrm{t} / \mathrm{ha})$ than $\mathrm{SC} 704(6.66 \mathrm{t} / \mathrm{ha})$.The lowest dry and wet ear weight were obtained from 
$250 \mathrm{~kg} / \mathrm{ha} \mathrm{N}$ with $6.60 \mathrm{t} / \mathrm{ha}$ and $15.80 \mathrm{t} / \mathrm{ha}$ respectively.There is no significant difference between $350 \mathrm{~kg} / \mathrm{ha} \mathrm{N}$ and $450 \mathrm{~kg} / \mathrm{ha} \mathrm{N}$ on dry and wet ear weight (Table 4and Table 6).

Table 3. Variance analysis of experimental traits

Source of variation df Silage yeild(t/ha) Leaf weight ( $\mathrm{t} / \mathrm{ha}) \quad$ stem weight(t/ha) Ear weight (t/ha)

\begin{tabular}{cccccc}
\hline Replication & 3 & $36.35 \mathrm{~ns}$ & $9.44 \mathrm{~ns}$ & $6.55 \mathrm{~ns}$ & $6.62 *$ \\
Row spacing & 2 & $0.14 \mathrm{~ns}$ & $6.95 \mathrm{~ns}$ & $5.54 \mathrm{~ns}$ & $0.45 \mathrm{~ns}$ \\
Error(a) & 6 & 17.66 & 2.71 & 6.53 & 4.05 \\
Cultivar(b) & 1 & $286.88^{*}$ & $0.03 \mathrm{~ns}$ & $239.88^{*}$ & $1.60^{*}$ \\
Row spacingx Cultivar & 2 & $29.92 \mathrm{~ns}$ & $3.38 \mathrm{~ns}$ & $5.52 \mathrm{~ns}$ & $2.09 \mathrm{~ns}$ \\
Error(b) & 9 & 25.59 & 4.72 & 6.97 & 9.84 \\
N(c) & 2 & $4.18 \mathrm{~ns}$ & $9.12 \mathrm{~ns}$ & $7.69 \mathrm{~ns}$ & $5.71 \mathrm{~ns}$ \\
Row spacingxN & 4 & $62.45^{*}$ & $1.87 \mathrm{~ns}$ & $17.39 \mathrm{~ns}$ & $9.34 \mathrm{~ns}$ \\
CultivarxN & 2 & $6.88 \mathrm{~ns}$ & $13.15 \mathrm{~ns}$ & $7.89 \mathrm{~ns}$ & $1.85 \mathrm{~ns}$ \\
Row spacingxCultivarxN & 4 & $17.99 * *$ & $5.29 \mathrm{~ns}$ & $3.54 \mathrm{~ns}$ & $3.57 \mathrm{~ns}$ \\
Error(c) & 36 & 15.37 & 2.69 & 4.03 & 3.88 \\
\hline$\% \mathrm{CV}$ & & 10.83 & 19.93 & 12.06 & 15.17 \\
\hline
\end{tabular}

$* * *$ and ns significant at the $5 \%, 1 \%$ and non significant respectively.

Table 4.-Mean comparison of different treatments for the studied agronomic characteristics in corn

$\begin{array}{lllll}\text { Treatments } & \text { Silage yield(t/ha) } & \text { Leaf weight (t/ha) } & \text { stem weight }(\mathrm{t} / \mathrm{ha}) & \text { Ear weight }(\mathrm{t} / \mathrm{ha})\end{array}$

$\begin{array}{ccccr}\text { Row spacing } & & & & \\ 65 \mathrm{~cm} & 36.30 \mathrm{a} & 6.02 \mathrm{a} & 17.18 \mathrm{a} & 13.10 \mathrm{a} \\ 75 \mathrm{~cm} & 36.19 \mathrm{a} & 7.09 \mathrm{a} & 16.27 \mathrm{a} & 12.83 \mathrm{a} \\ 85 \mathrm{~cm} & 36.15 \mathrm{a} & 6.64 \mathrm{a} & 16.47 \mathrm{a} & 13.04 \mathrm{a}\end{array}$

Cultivar

$\begin{array}{ccccc}\text { Sc704 } & 38.21 \mathrm{a} & 6.60 \mathrm{a} & 18.47 \mathrm{a} & 13.14 \mathrm{a} \\ \mathrm{Sc770} & 34.22 \mathrm{~b} & 6.56 \mathrm{a} & 14.82 \mathrm{~b} & 12.84 \mathrm{~b} \\ \mathrm{~N} & & & & \\ \mathrm{Kg} 250 & 34.21 \mathrm{~b} & 5.87 \mathrm{~b} & 15.80 \mathrm{~b} & 12.54 \mathrm{~b} \\ \mathrm{Kg} 350 & 36.74 \mathrm{a} & 6.99 \mathrm{a} & 16.65 \mathrm{a} & 13.10 \mathrm{a} \\ \mathrm{Kg} 450 & 37.30 \mathrm{a} & 6.89 \mathrm{a} & 17.07 \mathrm{a} & 13.34 \mathrm{a}\end{array}$

Means followed by the same letters in each column and factor are not significantly different by Duncan's test at $5 \%$ probability level.

3.8 Dry silage yield

SC704 (16.54 t/ha) and SC770 (15.92t/ha) were nearly similar for dry silage yield and had 
not significant effect on dry silage yield at 0.05 probability levels (Tables 6 ). The highest dry silage yield were produced in $350 \mathrm{~kg} / \mathrm{haN}$ (16.64 t/ha) and $450 \mathrm{~kg} / \mathrm{haN}(16.46 \mathrm{t} / \mathrm{ha}) \mathrm{plant} / \mathrm{ha}$ and the lowest dry silage yield (15.52 t/ha) were produced in $250 \mathrm{~kg} / \mathrm{haN}$. Row spacing had not significant difference on dry silage yield. $65 \mathrm{~cm}$ row spacing with $16.92 \mathrm{t} / \mathrm{ha}$ had highest dry silage yield, $75 \mathrm{~cm}$ row spacing had $15.83 \mathrm{t} / \mathrm{ha}$ and $85 \mathrm{~cm}$ row spacing had $15.91 \mathrm{t} / \mathrm{ha}$ dry silage yield (Table 6).

Table 5. Variance analysis of experimental traits

\begin{tabular}{cccccc}
\hline Source of variation & df & $\begin{array}{c}\text { Dry silage } \\
\text { yield(t/ha) }\end{array}$ & $\begin{array}{c}\text { Dry leaf weight } \\
(\mathrm{t} / \mathrm{ha})\end{array}$ & $\begin{array}{c}\text { Dry ear weight } \\
(\mathrm{t} / \mathrm{ha})\end{array}$ & $\begin{array}{c}\text { Dry stem } \\
\text { weight }(\mathrm{t} / \mathrm{ha})\end{array}$ \\
\hline Replication & 3 & $19.63 \mathrm{~ns}$ & $0.28 \mathrm{~ns}$ & $2.89^{*}$ & $5.61 \mathrm{~ns}$ \\
Row spacing & 2 & $8.36 \mathrm{~ns}$ & $0.15 \mathrm{~ns}$ & $2.01 \mathrm{~ns}$ & $2.70 \mathrm{~ns}$ \\
Error(a) & 6 & 29.63 & 0.29 & 10.84 & 4.35 \\
Cultivar(b) & 1 & $6.89 \mathrm{~ns}$ & $0.01 \mathrm{~ns}$ & $6.51^{*}$ & $27.44^{*}$ \\
Row spacingx & 2 & $4.79 \mathrm{~ns}$ & $0.04 \mathrm{~ns}$ & $0.47 \mathrm{~ns}$ & $2.29 \mathrm{~ns}$ \\
Cultivar & & 19.37 & 0.34 & 7.16 & 3.87 \\
Error(b) & 9 & $0.55 \mathrm{~ns}$ & $0.07 \mathrm{~ns}$ & $0.70 \mathrm{~ns}$ & $1.27 \mathrm{~ns}$ \\
N(c) & 2 & $31.93 *$ & $0.51 \mathrm{~ns}$ & $7.00 \mathrm{~ns}$ & $9.14 \mathrm{~ns}$ \\
Row spacingxN & 4 & $17.99 \mathrm{~ns}$ & $0.01 \mathrm{~ns}$ & $3.53 \mathrm{~ns}$ & $7.74 \mathrm{~ns}$ \\
CultivarxN & 2 & $37.35^{* *}$ & $0.60 \mathrm{~ns}$ & $10.64 \mathrm{~ns}$ & $5.04 \mathrm{~ns}$ \\
Row & 4 & 13.53 & 0.21 & 5.19 & 3.12 \\
spacingxCultivarxN & & 18.66 & 15.55 & 19.74 & 16.69 \\
Error(c) & 36 & $1 \% \mathrm{nd}$ & & \\
\hline \%CV & & &
\end{tabular}

$*$,** and ns significant at the $5 \%, 1 \%$ and non significant respectively.

Table 6. Mean comparison of different treatments for the studied agronomic characteristics in corn

\begin{tabular}{ccccc}
\hline Treatments & & & Dry ear yield(t/ha) & Dry stem weight $(\mathrm{t} / \mathrm{ha})$ \\
& Plant dry weight $(\mathrm{t} / \mathrm{ha})$ & Dry leaf yield(t/ha) & \\
\hline Row spacing & & & & \\
$65 \mathrm{~cm}$ & $16.92 \mathrm{a}$ & $2.11 \mathrm{a}$ & $7.29 \mathrm{a}$ & $7.52 \mathrm{a}$ \\
$75 \mathrm{~cm}$ & $15.83 \mathrm{a}$ & $2.01 \mathrm{a}$ & $6.75 \mathrm{a}$ & $7.07 \mathrm{a}$ \\
$85 \mathrm{~cm}$ & $15.91 \mathrm{a}$ & $2.21 \mathrm{a}$ & $6.84 \mathrm{a}$ & $6.86 \mathrm{a}$ \\
Cultivar & & & & \\
Sc704 & $16.54 \mathrm{a}$ & $2.11 \mathrm{a}$ & $6.66 \mathrm{~b}$ & $7.77 \mathrm{a}$ \\
$\mathrm{Sc770}$ & $15.92 \mathrm{a}$ & $2.13 \mathrm{a}$ & $7.26 \mathrm{a}$ & $6.53 \mathrm{~b}$ \\
$\mathrm{~N}$ & & & & \\
$\mathrm{Kg} 250$ & $15.52 \mathrm{~b}$ & $2.10 \mathrm{a}$ & $6.60 \mathrm{~b}$ & $6.82 \mathrm{~b}$ \\
$\mathrm{Kg} \mathrm{350}$ & $16.64 \mathrm{a}$ & $2.13 \mathrm{a}$ & $7.03 \mathrm{a}$ & $7.48 \mathrm{a}$ \\
$\mathrm{Kg} 450$ & $16.46 \mathrm{a}$ & $2.15 \mathrm{a}$ & $7.24 \mathrm{a}$ & $7.17 \mathrm{a}$ \\
\hline
\end{tabular}

Means followed by the same letters in each column and factor are not significantly different by Duncan's test at 5\% probability level. 
Means followed by the same letters in each column and factor are not significantly different by Duncan's test at $5 \%$ probability level.

\section{Knowledgement}

This project was supported financially by the Agricultural and Natural Resources Research Center of Mazandaran, highly appreciated.

\section{References}

Adediran, J. A., \& Banjoko, V. A. (1995). Response of Maize to Nitrogen, Phosphorus and Potassium fertilizers in the savanna zone of Nigeria. Commun Soil Science. Plant Anal., 26, 593-606.

Ali, M., Khalil., S. Ayaz., K. S., \& Marwat, M. I. ( 1998). Phenological stages, flag leaf area, plant height and leaves per plant of corn as influenced by phosphorus levels and plant spacing. Jornal of Agriculture, 14, 515- 522.

Allard, R.W. ( 1960). Principles of plant breeding. John Wiley and Sons Inc . NewYork, 485.

Andrade, F. H., Calvino, P., Cirilo, A., \& Barbieri, P. (2002). Yield responses to narrow rows depend on increased radiation interception. Argonomy Journal, 94, 975-980.

Asghar, A., Ali., W. Syed, H., Asif, M., Khaliq, T., \& Abid, A. A. (2010). Growth and yield of maize (Zea mays L.)cultivars affected by N.P.K application in different proportion. Pakistan Journal of Science, 62(4).

Brady, N. C. (1984). The nature and properties of Soils. Macmillan Publishing Company, New York, 152-158.

Bullock D. G, Nielsen RL, Nyquist W. E. ( 1988). A growth analysis comparison of corn grown in conventional and equidistant plant spacing. Crop Sci. 28, 254-258.

Cardwell, V. B. ( 1982). Fifty Years of Minnesota: Corn Production Sources of yield increases. Argonomy Journal, 74(6), 984-990.

Rajendran, C. R., \& Buresh, R. J. (2007). Environmental impact and economic benefits of sitespecific nutrient management(SSNM) in irrigated rice systems. Agriculture System, 93, 124.

Dipaolo, E., \& M. Rinaldi.(2008). Yield response of corn to irrigation and nitrogen fertilization in a Mediterranean environment. Field Crops Research, 105, 202-210.

Duncan WG. 1984. A theory to explain the relationship between corn population and grain yield. Crop Science, 24, 1141-1145.

Farnham, D. E. (2001). Row spacing, plant density, and hybrid effects on corn grain yield and moisture. Argonomy Journal, 93, 1049-1053.

Hashemi, M. H., Herbert, S. J., \& Putnam, D. H. ( 2005). Yield response of corn to crowding stress. American Society of Agronomy, 97, 839-846. http ://dx. doi. org/ 10.2134 / jeq 2014.12.0540.

Haque, M. M., Hamid, A., \& Bhuiyan, N. I. (2001). "Nutrient uptake and productivity as 
affected by nitrogen and potassium application levels $\mathrm{n}$ maize/sweet potato intercropping system".Korean J. Crop Science, 46(1), 1-5. http ://dx. doi. org/10.2135/ cropsci 2014.01.0025.

Kiniry, J. R., Tischler, C., Rosenthal, W. D., \& Gerik, T. J. (1992). Non structural carbohydrate utilization by sorghum and maize shaded during growth. Crop Science., 32, 131-137. http ://dx. doi. org/10.2135/ cropsci 2014.01.0025.

Kucharik, C. J. ( 2008). Contribution of planting date trends to increased maize yield in the central United States. Argonomy Journal.100:328-336.

Ottman M., \& Welch, L. (1989). Planting patterns and radiation interception, plant nutrient concentration, and yield in corn. Argonomy Journal, 81,167-174.

Pampolino. M.F.,I .J . Manguit.S. Ramanathan. H.C. Cines, P.S. Tan,T.T.N. Sanjeev, K.and A.S.Bangarwa.(1997). Yield and yield components of writer maize (Zea mays L). as inluenced byplant density and nitrogen levels. Agriculture Science. Digest (Karnal), 17, 181184.

Pedersen, P., \& Lauer, J. G. ( 2003). Corn and soybean responses to rotation sequence, row spacing, and tillage system. Argonomy Journal, 95, 965-971.

Rahimizadeh M. (2010). Nitrogen use efficiency of wheat as affected by preceding crop, application rate of nitrogen and crop residues. Australian Journal of Crop Science, 3, 89-93. http ://dx. doi. org/ 10.1.1.322.8551.

Saseendran.S.A., L.Ma, D.C.Nielsen, M.F.vigil and .R.Ahuja, (2005). Simulating planting date effects on corn production using RZWQM and CERES maize models. Argonomy Journal, 97, 58-71.

Shanti, K. V. P., Rao, M. R., Reddy, M. S., \& Sarma, R. S. (1997). Response of maize (Zea mays) hybrid and composite to different levels of nitrogen. Indian Journal of Agricultural science, 67, 424-425.

Subedi, K. D., Ma, B. L., \& Smith, D. L. (2006). Response of a leafy and nonleafy maize hybrid to population densities and fertilizer nitrogen Levels. Crop Science. 46:1860-1869. http ://dx. doi. org/10.2135/ cropsci 2014.01.0025.

Tad, W. P. (2004). Thermody mamice of the cornethanol biofuel cycle. Critical Reviews in Plant Sciences, 23(6), 519-567.

Tollenaar M., \& Aguilera, A. (1992) .Radiation use efficiency of an old and new maize hybrid. Argonomy Journal, 84, 536-541.

Westage, M. E, Forcella F, Riecosky D. C., \& Somsen, J. (1997). Rapid canopy closure for maize production in thenorthern US corn belt: Radiation use efficiency and grain yield. Field Crops Research, 49, 249-258.

Widdicombe, W. D., \& Thelen, K. D. (2002). Row width and plant density effects on corn grain production in the northern Corn Belt. Argonomy Journal, 94, 1020-1023.

Norwood, C. A. ( 2000). Water use and yield of limited irrigated and dryland corn.Soil Science Society of American Journal, 64, 365-370. 


\section{Copyright Disclaimer}

Copyright for this article is retained by the author(s), with first publication rights granted to the journal.

This is an open-access article distributed under the terms and conditions of the Creative Commons Attribution license (http://creativecommons.org/licenses/by/3.0/). 